\title{
PENGARUH MODEL PEMBELAJARAN MIND MAPPING BERBANTUAN MEDIA AUDIO-VISUALTERHADAP KOMPETENSI PENGETAHUAN IPS
}

\author{
Ni Luh Putu Ekayanti' ${ }^{1}$ I Wayan Darsana², I Wayan Sujana ${ }^{3}$ \\ 1 Jurusan Pendidikan Guru Sekolah Dasar UniversitasPendidikan Ganesha Singaraja, Indonesia \\ 2 Jurusan Pendidikan Guru Sekolah Dasar UniversitasPendidikan Ganesha Singaraja, Indonesia \\ ${ }^{3}$ Jurusan Pendidikan Guru Sekolah Dasar UniversitasPendidikan Ganesha Singaraja, Indonesia
}

\begin{abstract}
Abstrak
Penelitian ini bertujuan untuk mengetahui pengaruh yang signifikan model pembelajaran mind mapping berbantuan media audio-visual terhadap kompetensi pengetahuan IPS kelas IV SD Gugus VIII Kecamatan Abiansemal tahun ajaran 2018/2019. Penelitian ini merupakan penelitian eksperimen semu dengan desain penelitian yang digunakan rancangan kelompok nonekuivalen. Populasi dalam penelitian ini seluruh kelas IV SD Gugus VIII Kecamatan Abiansemal tahun ajaran 2018/2019 sebanyak 260 siswa. Sampel ditentukan dengan teknik random sampling. Metode pengumpulan data dalam penelitian ini menggunakan metode tes. Instrumen yang digunakan untuk mengumpulkan kompetensi pengetahuan IPS dengan menggunakan tes objektif dalam bentuk pilihan ganda biasa dengan empat pilihan. Data dianalisis dengan menggunakan uji-t. Berdasarkan pengolahan data diperoleh hasil penelitian yaitu nilai rata-rata gain skor kelompok eksperimen $(0,53)$ dan nilai rata-rata gain skor kelompok kontrol $(0,45)$, maka nilai rata-rata gain skor kelompok eksperimen lebih tinggi dari pada nilai rata-rata gain skor kelompok kontrol $(0,53>0,45)$. Berdasarkan hasil uji-t dengan derajat kebebasan $(\mathrm{dk}=34+33-2)$ dan pada taraf signifikan $5 \%$ diperoleh $t_{\text {hitung }}>\mathrm{t}_{\text {tabel }}(3,333>2,000) \mathrm{maka}_{0}$ ditolak dan $\mathrm{H}_{\mathrm{a}}$ diterima. Ini berarti terdapat perbedaan yang signifikan kompetensi pengetahuan IPS siswa yang dibelajarkan melalui model pembelajaran mind mapping berbantuan media audio-visual dengan siswa yang dibelajarkan melalui pembelajaran konvensional kelas IV SD Gugus VIII Kecamatan Abiansemal tahun ajaran 2018/2019. Dengan demikian dapat disimpulkan bahwa terdapat pengaruh yang signifikan model pembelajaran mind mapping berbantuan media audio-visual terhadap kompetensi pengetahuan IPS pada kelas IV SD Gugus VIII Kecamatan Abiansemal tahun ajaran $2018 / 2019$.
\end{abstract}

\section{Pendahuluan}

Pendidikan merupakan usaha sadar dalam membina dan mengembangkan hakikat dan martabat manusia secara utuh, menyeluruh ,menarik, menyenangkan dan menggembirakan. Dalam era globalisasi, pendidikan menjadi salah satu tuntutan bagi setiap individu dalam mengoptimalkan dan pemenuh kebutuhan hidup bagi setiap orang, sesuai dengan pola dan tugas perkembangannya, serta tuntutan bagi seseorang yang akan terjun di dunia kerja (Yusuf ,2015).

Pada pelaksanakan pendidikan perlu adanya suatu kurikulum yang dapat mendukung proses pendidikan yang baik. Sesuai dengan UU Sisdiknas kurikulum adalah seperangkat rencana dan pengaturan mengenai tujuan, isi, dan bahan pelajaran serta cara yang digunakan sebagai pedoman penyelenggaraan kegiatan pembelajaran untuk mencapai tujuan pendidikan tertentu.

Peranan dan fungsi kurikulum menyesuaikan dengan keberadaan manusia yang selalu menghadapi perubahan. Perubahan kurikulum KTSP menjadi Kurikulum 2013 di Indonesia bertujuan untuk mempersiapkan manusia Indonesia agar memiliki kemampuan hidup sebagai pribadi dan warga negara yang beriman, produktif, kreatif, inovatif, dan afektif serta mampu 
berkontribusi pada kehidupan bermasyarakat, berbangsa, dan bernegara. (Permendikbud no 57 tahun 2014 lampiran I).

Penerapan kurikulum 2013 dilapangan masih membuat siswa secara pasif menyerap struktur yang diberikan oleh guru yang terdapat di buku pelajaran. Dalam kurikulum 2013 siswa dituntut melalui beberapa proses secara aktif mencari, mengolah, mengkonstruksi, dan menerapkan pengetahuan. Dari berbagai muatan materi di sekolah dasar, Ilmu Pengetahuan Sosial (IPS) merupakan salah satu muatan materi yang sering muncul dalam pembelajaran karena berhubungan dengan berbagai aktivitas kehidupan dan masalah sehari-hari.

"Ilmu Pengetahuan Sosial merupakan bidang studi yang mengajari, menelaah, menganalisis, gejala dan masalah sosial di masyarakat dengan meninjau dari berbagai aspek kehidupan atau satu paduan" (Sardjiyo dkk, 2014:26).

Pentingnya pembelajaran dengan muatan Ilmu Pengetahuan Sosial sesuai kurikulum 2013, seyogianya disajikan dengan cara yang menarik, dengan menggunakan permasalahan yang ada disekeliling siswa sebagai suatu konteks bagi siswa untuk berpikir kritis, sehingga siswa merasa tertarik dan melibatkan diri secara aktif dalam proses belajar mengajar sehubungan dengan tujuan pembelajaran tersebut. Pembelajaran dengan menyajikan permasalahan riil sebagai suatu konteks bagi siswa untuk berpikir kritis masih jarang digunakan terutama untuk siswa yang duduk di bangku sekolah dasar. Kegiatan pembelajaran yang sering dilakukan kepada siswa di kelas masih menggunakan variasi beberapa metode pembelajaran, seperti metode ceramah, metode Tanya jawab, dan metode penugasan.Dalam pendidikan terdapat suatu pembelajaran yang dilakukan oleh guru dan siswa. Semua guru pasti mengharapkan agar setiap pembelajaran dapat mencapai hasil belajar yang sebaik-baiknya.

"Model Mind Mapping adalah teknik pemanfaatan seluruh otak dengan menggunakan citra visual dan prasarana grafis lainnya untuk membentuk kesan. Otak sering kali mengingat informasi dalam bentuk gambar ,simbol,suara,bentuk-bentuk ,dan perasaan" (Shoimin, 2014:105). Model pembelajaran Mind Mapping membantu pembelajar mengatasi kesulitan ,mengetahui apa yang hendak ditulis, serta bagaimana mengorganisasi gagasan ,sebab teknik ini mampu membantu pembelajar menemukan gagasan ,mengetahui apa yang akan ditulis pembelajar, serta bagaimana memulainya

Penggunaan suatu model Mind Mapping agar tercapainya hasil yang maksimal maka dibantu dengan penggunaan media audio visual ini diharapkan adanya ketertarikan siswa dalam mengikuti serta memberi kesan menarik dalam proses pembelajaran. "Media audio visual adalah media penyaluran pesan dengan memanfaatkan indra pendengaran dan penglihatan" (Arsyad,2011:148). Di antara jenis media audiovisual ini adalah media film,video, dan televise.

Berdasarkan pemaparan tersebut, dilakukan penelitian yang berjudul Pengaruh Model PembelajaranMind Mapping Berbantuan Media Audio Visual Terhadap Kompetensi Pengetahuan IPS Siswa Kelas IV Gugus VIII Kecamatan Abiansemal Tahun Ajaran 2018/2019.

\section{Metode}

Jenis penelitian yang dilakukan dalam penelitian ini adalah penelitian kuantitatif dengan desain ekperimental yaitu quasi eksperimen (Eksperimen Semu). "Desain ini mempunyai kelompok kontrol, tetapi tidak bisa sepenuhnya mengontrol variabel-variabel luar yang mempengaruhi pelaksanaan eksperimen" (Sugiyono, 2016:114). Desain eksperimen yang digunakan adalah "Nonequivalent control group design".

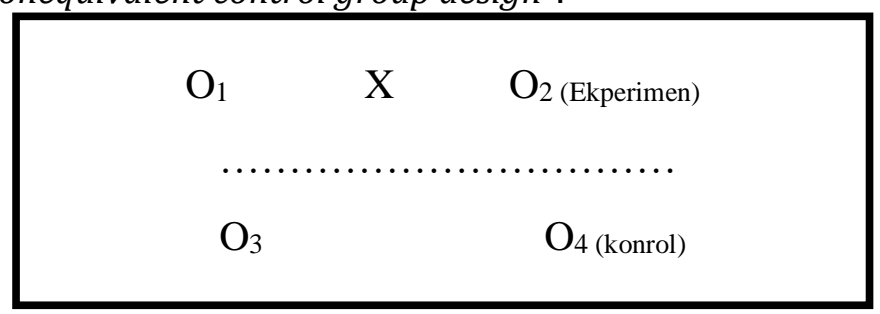

Gambar . 1 Nonequivalent control group design (Sumber : Setyosari, 2015:211) 
Pelaksanaan penelitian ini terdiri dari tiga tahapan yaitu, tahap persiapan pada tahap persiapan eksperimen ini kegiatan yang akan dilakukan adalah: Melakukan wawancara dengan kepala gugus SD yang ada di Gugus VIII Kecamatan Abiansemal dan wali kelas IV di masingmasing sekolah untuk mengetahui ada atau tidaknya kelas unggulan di SD Gugus VIII Kecamatan Abiansemal. Mempersiapkan sarana pendukung pembelajaran seperti, menyusun RPP (Rencana Pelaksanaan Pembelajaran), LKS, media pembelajaran yang akan digunakan dalam proses pembelajaran. Mengkonsultasikan instrumen penelitian pre test dan post tes bersama wali kelas dan dosen pembimbing. Mengkonsultasikan RPP dan media pembelajaran bersama wali kelas dan dosen pembimbing. Mengadakan uji coba instrumen penelitian. Melakukan pengundian untuk menentukan kelas eksperimen dan kelas kontrol. Pada tahap pelaksanaan eksperimen, kegiatan yang dilakukan adalah: Memberikan perlakuan (treatment) pada kelas eksperimen dengan menerapkan model mind mapping berbantuan media audio visual. Perlakuan di berikan sebanyak 6 kali di kelas eksperimen dan 6 kali di kelas kontrol. Jumlah perlakuan yang di berikan telah disesuaikan dengan jam pelajaran terkait materi dalam penelitian ini yang telah di atur dalam kurikulum dan silabus Memberikan post-test pada akhir eksperimen, baik untuk kelompok eksperimen maupun kontrol. Saat tahap akhir eksperimen kegiatan yang di tempuh adalah: Menganalisis data hasil penelitian. Melakukan uji hipotesis.

Dalam melakukan penelitian, terlebih dahulu menentukan populasi yang dijadikan penelitian. "Populasi adalah wilayah generalisasi yang terdiri atas obyek atau subyek yang mempunyai kualitas dan karakteristik tertentu yang ditetapkan oleh penelitian untuk dipelajari dan kemudian ditarik kesimpulannya" (Sugiyono, 2013:61). Sedangkan menurut Sugiyono (2013:61)“Populasi adalah wilayah generalisasi yang terdiri atas obyek atau subyek yang mempunyai kualitas dan karakteristik tertentu yang ditetapkan oleh penelitian untuk dipelajari dan kemudian ditarik kesimpulannya" Sedangkan menurut Agung (2014:69) menyatakan bahwa "Populasi adalah keseluruhan obyek dalam suatu penelitian". Jadi dapat disimpulkan pengertian populasi adalah kumpulan dari orang yang memiliki kualitas dan karakteristik tertentu yang ingin diteliti oleh peneliti lalu dipelajari dan ditarik kesimpulan. Populasi dari penelitian ini adalah seluruh siswa kelas IV (empat) SD Gugus VIII Kecamatan Abiansemal tahun ajaran 2018/2019 yang terdiri dari kelas dalam 9 sekolah dasar jumlah populasi ini adalah 260 orang.

Tabel.1

Nama Sekolah dan Jumlah Siswa Kelas IV SD Gugus VIII Kecamatan Abiansemal

\begin{tabular}{lll}
\hline Sekolah & Kelas & Jumlah siswa \\
\hline SDN 1 Sibangkaja & IV & 34 \\
\hline SDN 2 Sibangkaja & IV A & 27 \\
\cline { 2 - 3 } & IV B & 25 \\
\hline SDN 3 Sibangkaja & IV & 31 \\
\hline SDN 4 Sibangkaja & IV & 33 \\
\hline SDN 1 Sibang Gede & IV & 31 \\
\hline SDN 2 Sibang Gede & IV & 33 \\
\hline SDN 3 Sibang Gede & IV & 16 \\
\hline SDN 4 Sibang Gede & IV & 30 \\
\hline Jumlah Total 9 Kelas & & 260 Siswa \\
\hline
\end{tabular}

Setelah mengetahui populasi langkah selanjutnya adalah menentukan sampel penelitian. Sampel adalah "bagian dari jumlah dan karakteristik yang dimiliki oleh populasi" (Sugiyono, 2013:62).Menurut Sugiyono (2013:62) Sampel adalah "bagian dari jumlah dan karakteristik yang dimiliki oleh populasi". Menurut Agung, (2014:69) menyatakan bahwa "Sampel adalah sebagian dari populasi yang diambil, yang dianggap mewakili seluruh populasi dan diambil dengan teknik tertentu".Jadi dapat disimpulkan bahwa sampel adalah bagian dari populasi yang Ni Luh Putu Ekayanti, I Wayan Darsana, I Wayan Sujana. (2019) 
mewakili anggota populasi. Dari pengertian tersebut memberi gambaran bahwa sampel mewakili populasi untuk dijadikan sebagai sumber data penelitian. Penggunaan sampel bertujuan untuk menghemat waktu, tenaga, dan biaya dalam melakukan penelitian.

Teknik pengambilan sampel pada penelitian ini adalah random sampling, karena pengambilan anggota dari populasi dilakukan secara acak. Pengambilan sampel secara acak dapat dilakukan dengan cara undian. Pada teknik ini, setiap anggota populasi memiliki kesempatan yang sama untuk menjadi anggota populasi. Pemilihan sampel penelitian ini tidak dilakukannya pengacakan individu melainkan hanya pengacakan kelas, karena tidak bisa mengubah kelas yang telah terbentuk sebelumnya. Kelas yang dipilih telah terbentuk tanpa campur tangan peneliti sehingga kemungkinan pengaruh-pengaruh dari keadaan subjek mengetahui dirinya dilibatkan dalam eksperimen dapat dikurangi sehingga penelitian ini benarbenar menggambarkan pengaruh perlakuan yang diberikan.

Setiap kelas yang ada dalam populasi diberi nomor urut terlebih dahulu kemudian melakukan random dan diambil 2 kelas sebagai sampel. Berdasarkan hasil wawancara yang diperoleh dari ketua Gugus VIII Kecamatan Abiansemal serta guru kelas IV di masing-masing SD Gugus VIII yaitu bahwa kelas IV dari 8 sekolah dengan 9 kelas yang ada di Gugus VIII Kecamatan Abiansemal setara secara akademik yang memiliki rata-rata tidak jauh beda . dikatakan setara karena pengelompokan siswa ke dalam kelas tersebar secara merata antara siswa yang memiliki kemampuan tinggi, sedang dan rendah. Dari keterangan tersebut berarti tidak terdapat kelas unggulan maupun non unggulan. Setelah mengetahui bahwa kelas memiliki kesetaraan , langkah selanjutnya adalah melakukan pengundian tahap kedua yaitu menentukan kelompok kontrol dan kelompok eksperimen. Kedua kertas gulungan tersebut kemudian dikocok dan diambil satu per satu gulungan kertas. Gulungan yang pertama adalah kelas IV SD No. 1 Sibangkaja dijadikan kelompok kelas eksperimen dan gulungan kertas kedua yang muncul adalah kelas IV SD No.4 Sibangkaja dijadikan kelompok kelas kontrol.

"Validitas internal bersumber dari pelaksanaan penelitian itu sendiri yang berkaitan dengan perlakuan yang diberikan apakah benar-benar menyebabkan hasil yang diobservasi dalam penelitian"(Cahyani:2018). Adapun beberapa hal yang terdapat dalam validitas internal yang dapat menjadi ancaman dalam penelitian ini adalah sebagai berikut.

Sejarah, "Istilah sejarah merujuk pada peristiwa yang terjadi di sekitar atau lingkungan pada saat yang sama ketika variabel ekperimental tersebut dilakukan melalui pengujian" (Setyosari, 2015:180). Cara yang dapat digunakan untuk mengontrol validitas internal berdasarkan faktor sejarah ini dapat dikendalikan dengan menggunakan kelompok kontrol yang memiliki sejarah yang sama. Dilihat dari sejarah pembentukan kelas di kelompok kontrol maupun kelompok eksperimen, tidak dibentuk secara khusus. Serta kelompok eksperimen dan kelompok kontrol juga menggunakan kurikulum yang sama yaitu kurikulum 2013. Dengan demikian, siswa pada kelompok eksperimen dan kelompok kontrol memiliki pengalaman belajar yang sama.

Bias seleksi, penelitian eksperimen yang mencoba membandingkan pengaruh perlakuan pada kelompok subjek yang berbeda, kelompok yang mengalami suatu perlakuan mungkin lebih cerdas, lebih reseptif daripada kelompok subjek yang tidak mengalami perlakuan atau percobaan (Setyosari, 2015:182). Untuk menghindari hal tersebut maka dilakukan penyetaraan kelompok sampel menggunakan surat keterangan kesetaraan dari ketua gugus bahwa menyatakan SD yang ada di Gugus 8 Kecamatan Abiansemal bahwa semua sekolah setara . Hal tersebut dilakukan untuk mendapatkan kelas yang setara secara akademik sehingga perubahan kompetensi pengetahuan terjadi karena adanya perlakuan bukan perbedaan kelompok subjek.

Kematangan ,"Kematangan merujuk pada proses perubahan yang terjadi dalam diri subjek yang dijadikan kelompok eksperimen" (Setyosari, 2015:183). Untuk mengatasi hal tersebut maka dilakukaan penelitian dengan penggunaan periode waktu yang sama untuk kelompok eksperimen dan kelompok kontrol, sehingga akan memiliki kesamaan pengalaman kematangan. 
Periode waktu yang digunakan adalah enam 6 kali pertemuan untuk melakukan perlakuan pada kelompok eksperimen dan kelompok kontrol selain itu penggunaan kelompok kontrol yang memiliki siswa dengan usia yang sama dengan kelompok eksperimen yaitu dari umur 9-11 tahun. Jadi, kesimpulan dari penelitian ini terbebas dari ancaman faktor kematangan.

Pengujian Sebelumnya (Pretesting) "Validitas internal yang berkaitan dengan pre-test merujuk pada fakta bahwa perubahan dalam variabel hasil mungkin sebagai akibat proses pengukuran sebelum pemberian perlakuan bukannya pengaruh perlakuan itu sendiri" (Setyosari, 2015). Cara yang digunakan untuk mengontrol faktor tersebut dalam penelitian ini adalah dengan mengacak nomor soal pre-test untuk membuat soal post-test. Dan menganalisis skor perolehan yang ternormalisasikan (gain score normalisation) sehingga perubahan yang terjadi karena adanya perlakuan bukan pemberian tes yang dilakukan sebelumnya.

Sikap Subjek , "Pada penelitian dapat terjadi subjek menyadari dirinya menjadi partisipan dalam eksperimen sehingga timbul perasaan bangga karena ada yang memperhatikan apalagi diketahui bahwa penelitian ini adalah untuk memperbaiki keadaan subjek" (Dantes, 2014:9). Pada penelitian ini sikap subjek dapat diatasi dengan mengupayakan siswa agar menganggap bahwa penelitian ini adalah suatu hal yang rutin dan dalam penelitian ini yang mengajar adalah guru kelas itu sendiri sehingga siswa tidak menimbukan reaksi atau sikap yang berlebihan.

Selain faktor internal, ada faktor lain yang bersifat eksternal yang memiliki pengaruh pada hasil penelitian yaitu validitas eksternal. "validitas eksternal merujuk pada generalisasi dan berkenaan dengan seberapa jauh kita dapat menggeneralisasi hasil penelitian di luar latar penelitian" (Setyosari, 2015:192). Ancaman validitas eksternal yang perlu diperhatikan serta cara mengatasi dalam penelitian ini adalah interaksi antara seleksi subjek dengan perlakuan membicarakan mengenai hubungan yang terjadi dapat digeneralisasikan terhadap kategori subjek yang dapat menjadi ancaman validitas ekssternal yang tinggi perlu dipertimbangkan karakteristik subjek dengan perlakuan yang diberikan. Pada penelitian ini, dilakukan pemilihan anggota secara acak (random) dalam penentuan sampel agar dapat diperoleh sampel yang mewakili populasi. Teknik sampling yang digunakan dalam penelitian ini yaitu teknik Random Sampling dengan melakukan pengundian pada populasi yang sudah terbentuk dalam kelas-kelas ,jadi setiap kelas dalam populasi memiliki peluang yang sama untuk dijadikan sampel penelitian. Hasilnya dapat digeneralisasikan pada populasi siswa kelas IV di SD Gugus VIII Kecamatan Abiansemal.

Dalam penelitian ini data yang akan dianalisis adalah data kompetensi pengetahuan IPS siswa, untuk mendapatkan data tersebut digunakan tes kompetensi pengetahuan IPS. Tes kompetensi pengetahuan IPS yang digunakan dalam penelitian ini disusun oleh peneliti sendiri. Sebelum memberikan tes tersebut kepada siswa dilakukan pengujian untuk menguji kelayakan instrument. Tes yang akan digunakan untuk mengukur kompetensi pengetahuan berupa tes objektif dalam bentuk pilihan ganda biasa yang berjumlah 50 butir tes yang nantinya akan dilakukan pengujian instrumen yaitu uji validitas, reliabilitas, daya beda dan indeks kesukaran. sebagai berikut:

Uji validitas yang digunakan dalam penelitian yaitu uji validitas isi dan validitas butir "Pengujian validitas isi dilakukan dengan membandingkan antara isi instrument dengan materi pelajaran yang telah diajarkan .atau tidaknya suatu tes hasil belajar dari segi isinya" (Sugiyono,2013: 353). Validitas isi dapat dilakukan dengan cara membandingkan antara isi instrument dengan isi atau rancangan yang telah ditetapkan. Untuk mendapatkan validitas isi dari tes kompetensi pengetahuan IPS maka ditempuh cara dengan menyusun soal berdasarkan kisi - kisi yang materinya diambil dari kurikulum maupun buku pelajaran. Tes kompetensi dikatakan valid apabila materi tes tersebut betul-betul representatif terhadap bahan pembelajaran yang akan dibelajarkan terhadap siswa. Uji validitas butir digunakan untuk mengukur validitas butir tes kompetensi pengetahuan IPS dalam bentuk pilihan ganda (objektif) 
digunakan rumus koefisien korelasi point biserial $\left(\mathrm{r}_{\mathrm{pbi}}\right)$ karena bersifat dikotomi. Adapun rumus yang digunakan adalah sebagai berikut.

$$
\mathrm{r}_{\mathrm{pbi}}=\left[\frac{\mathrm{M}_{\mathrm{P}}-\mathrm{M}_{\mathrm{t}}}{\mathrm{SD}_{\mathrm{t}}}\right]\left(\sqrt{\frac{\mathrm{p}}{\mathrm{q}}}\right)
$$

(Yusuf, 2015:71)

Uji reliabilitas dilakukan hanya pada butir soal yang telah diuji validitas butir tes dan dinyatakan valid."Suatu instrumen penelitian dikatakan reliabilitas apabila alat ukur itu diujikan kepada objek atau subjek yang sama secara berulang-ulang, hasilnya akan tetap sama dan konsisten , stabil, atau relative sama"(Yusuf, 2015:74). Uji reliabilitas tes yang bersifat dikotomi dan heterogen ditentukan dengan rumus Kuder Richardson20 (KR-20), yaitu:

$$
r_{11}=\left(\frac{n}{n-1}\right)\left(\frac{s_{t}^{2}-\sum p q}{s_{t}^{2}}\right)
$$

(Sudijono, 2015:253)

Daya pembeda soal merupakan kemampuan suatu soal untuk dapat membedakan antara siswa yang berkemampuan tinggi dengan siswa yang berkemampuan rendah. Menurut Agung (2016:92) "daya beda butir tes ialah kemampuan butir tes tersebut membedakan antara testee kelompok atas (pintar) dan testee kelompok bawah (lemah)". berikut.

Untuk menghitung daya pembeda setiap butir soal dapat digunakan rumus sebagai

$$
\mathrm{D}=\frac{\mathrm{B}_{\mathrm{A}}}{\mathrm{J}_{\mathrm{A}}}-\frac{\mathrm{B}_{\mathrm{B}}}{\mathrm{J}_{\mathrm{B}}}=\mathrm{P}_{\mathrm{A}}-\mathrm{P}_{\mathrm{B}}
$$

(Arikunto, 2015: 288)

Tingkat kesukaran suatu tes dapat dilihat dari kesanggupan atau kemampuan siswa menjawab tes yang diberikan. Kebaikan suatu tes dapat dilihat dari tingkat kesulitan dari masing-masing item. Terlalu mudah dan terlalu sukar adalah hal yang tidak baik. Tingkat kesukaran suatu item tidak berlaku universal, tetapi hanya berlaku untuk kelompok yang dikenai oleh tes yang dimaksud (Yusuf, 2015:254).

Rumus indeks kesukaran adalah sebagai berikut.

$$
\mathrm{P}=\frac{\mathrm{B}}{\mathrm{Js}}
$$

$$
\text { ( Sudijono,2015: 372) }
$$

Tes objektif pilihan ganda biasa ini meliputi 4 pilihan jawaban (a, b, c atau d), dengan jumlah pertanyaan diperoleh 30 butir soal yang telah divalidasi. Setiap item diberikan skor 1 bila siswa menjawab dengan benar (jawaban disesuaikan dengan kunci jawaban) dan skor 0 bila siswa menjawab salah. Skor setiap jawaban dijumlahkan dan jumlah tersebut menjadi skor variabel kompetensi pengetahuan IPS yang bergerak dari kisaran 0 - 30. 0 merupakan skor minimal dan 30 merupakan skor maksimal tes kompetensi pengetahuan IPS. Analisis data dalam penelitian kuantitatif merupakan kegiatan setelah data dari seluruh responden atau sumber data lain terkumpul. Data hasil pre-test dan post-test yang terkumpul dari kelompok eksperimen dan kelompok kontrol dianalisis terlebih dahulu dengan mencari gain skor yang dinormalisasi. Analisis statistik inferensial adalah statistik yang dipakai untuk melakukan analisis data dengan cara membuat kesimpulan yang berlaku secara umum. Statistik infrensial menurut Sugiyono (2016:209) "Statistik inferensial adalah teknik statistik yang digunakan untuk menganalisis data sampel dan hasilnya diberlakukan untuk populasi". Sebelum dilakukan uji hipotesis terlebih dahulu dilakukan uji prasyarat analisis data. Pada uji prasyarat analisis data dilakukan uji normalitas sebaran data dan uji homogenitas varian. Menghitung uji normalitas dalam penelitian ini menggunakan uji Kolmogorov-Smirnov. Kriteria pengujian adalah apabila nilai 
maksimum $[F r-F S] \leq$ nilai tabel Kolmogorov-Smirnov, maka data berdistribusi normal. Sebaliknya jika maksimum $[F r-F s]>$ nilai tabel Kolmogorov-Smirnov, maka data tidak berdistribusi normal. Uji homogenitas dilakukan untuk menunjukkan bahwa perbedaan yang terjadi pada uji hipotesis benar-benar terjadi akibat adanya perbedaan antar kelompok (Agung,2016:67). Uji homogenitas varians untuk kedua kelompok digunakan uji Fisher (F). Pengujian dilakukan pada taraf signifikansi $5 \%$ dengan derajat kebebasan untuk pembilang $\mathrm{n}_{1}-$ 1 dan derajat kebebasan untuk penyebut $\mathrm{n}_{2}-1$. Kriteria dalam pengujian ini adalah jika $F_{\text {hitung }} \leq F_{\text {tabel }}$, maka sampel homogen. Sebaliknya jika $F_{\text {hitung }}>F_{\text {tabel }}$, maka sampel tidak homogen.

Jika data yang diperoleh sudah memenuhi prasyarat uji normalitas dan homogenitas maka analisis yang digunakan adalah statistik parametris. Analisis statistik yang digunakan untuk menguji hipotesis penelitian ini adalah uji beda mean ( $u j i \mathrm{t}$ ). Uji Hipotesis menggunakan uji-t dengan rumus polled varians. Rumus uji-t dengan rumus polled varians digunakan bila jumlah anggota sampel sama $\mathrm{n}_{1} \neq \mathrm{n}_{2}$ dan varians homogen. Rumus uji-t dengan rumus polled varians sebagai berikut.

Rumus t-tes yang digunakan.

$$
\mathrm{t}=\frac{\overline{\mathrm{X}}_{1}-\overline{\mathrm{X}}_{2}}{\sqrt{\frac{\left(\mathrm{n}_{1}-1\right) \mathrm{S}_{1}^{2}+\left(\mathrm{n}_{2}-1\right) \mathrm{S}_{2}^{2}}{\mathrm{n}_{1}+\mathrm{n}_{2}-2}\left(\frac{1}{\mathrm{n}_{1}}+\frac{1}{\mathrm{n}_{2}}\right)}}
$$

(Koyan, 2012:37)

\section{Hasil dan Pembahasan}

Kelompok eksperimen dalam penelitian ini adalah kelas IV SD No 1 Sibangkaja yang bejumlah 34 orang siswa. Setelah diberikan pre-test dilanjutkan dengan pemberian perlakuan dengan model pembelajaran Mind Mapping berbantuan media Audio-visual sebanyak 6 kali pada kelompok eksperimen, di akhir penelitian siswa diberikan posttest untuk memperoleh data kompetensi pengetahuan IPS siswa. Setelah memperoleh skor posttest kemudian dicari gain skor yang dinormalisasikan dari hasil pre-test dan post-test.

Tabel 2. Deskripsi Data Gain Skor Kompetensi Pengetahuan IPS Siswa Kelas IV SD No 1 Sibangkaja Pada Kelompok Eksperimen

\begin{tabular}{ll}
\hline Rata-rata & 0,53 \\
\hline Standar Deviasi & 0,12 \\
\hline Varians & 0,014 \\
\hline
\end{tabular}

Berdasarkan hasil perhitungan di atas, pengelompokkan distribusi frekuensi untuk kompetensi pengetahuan IPS pada kelompok eksperimen diperoleh rata-rata gain skor adalah 0,53. Kelompok kontrol dalam penelitian ini adalah kelas IV SD No 4 Sibangkaja yang bejumlah 33 orang siswa. Setelah diberikan pretest dilanjutkan dengan pemberian perlakuan dengan pembelajaran konvensional sebanyak 6 kali pada kelompok kontrol, di akhir penelitian siswa diberikan post-test untuk memperoleh data kompetensi pengetahuan IPS siswa. Setelah memperoleh skor post-test kemudian dicari gain skor yang dinormalisasikan dari hasil pre-test dan post-test

Tabel 3. Deskripsi Data Gain Skor Kompetensi Pengetahuan IPS Siswa Kelas IV SD No 4 Sibangkaja Pada Kelompok Kontrol

\begin{tabular}{ll}
\hline Rata-rata & 0,45 \\
\hline Standar Deviasi & 0,11 \\
\hline Varians & 0,012 \\
\hline
\end{tabular}

Ni Luh Putu Ekayanti, I Wayan Darsana, I Wayan Sujana. (2019)

Pengaruh Model Pembelajaran Mind Mapping Berbantuan Media Audio-Visualterhadap 
Berdasarkan hasil perhitungan di atas, pengelompokkan distribusi frekuensi untuk kompetensi pengetahuan IPS pada kelompok kontrol diperoleh nilai rata-rata gain skor yaitu 0,45 . Uji homogenitas varian dilakukan berdasarkan data kompetensi pengetahuan IPS yang menggunakan data gain skor kelompok yang dibelajarkan melalui model pembelajaran Mind Mapping berbantuan media audio-visual dan kelompok yang dibelajarkan melalui pembelajaran konvensional. Jumlah masing-masing kelompok analisis adalah 34 untuk kelompok eksperimen dan 33 untuk kelompok kontrol. Untuk menentukan homogenitas variansnya menggunakan uji F. Dari hasil perhitungan, diperoleh $\mathrm{F}_{\text {hitung }}=1,17$ sedangkan $\mathrm{F}_{\text {tabel }}$ pada taraf signifikansi $5 \%$ dengan $\mathrm{dk}(33,32)$ adalah 1,80. Ini berarti $\mathrm{F}_{\text {hitung }}=1,17<\mathrm{F}_{\text {tabel }}(\alpha=0,05)=1,80$ maka data homogen.

Berdasarkan hasil uji normalitas sebaran data dan uji homogenitas varians diperoleh data kedua kelompok berdistribusi normal dan varians kedua kelompok homogen, maka uji statistik yang digunakan dalam penelitian ini adalah uji-t dengan rumus polled varians. Dengan kriteria pengujian adalah Ho ditolak jika tabel $t_{\text {hitung }}>t_{\text {tabel }}$ dihitung dengan $d k=n 1+n 2-2, d k=34+33-$ $2=65$ pada taraf signifikansi 5\%. Adapun rekapitulasi hasil uji hipotesis pada tabel sebagai berikut.

Tabel 4. Hasil Uji Hipotesis

\begin{tabular}{|c|c|c|c|c|c|c|}
\hline Sampel & Rata-rata & Varians & $\mathrm{N}$ & $t_{\text {hitung }}$ & $t_{\text {tabel }}$ & Kesimpulan \\
\hline $\begin{array}{l}\text { Kelompok } \\
\text { Eksperimen }\end{array}$ & 0,53 & 0,014 & 34 & & & \\
\hline $\begin{array}{l}\text { Kelompok } \\
\text { Kontrol }\end{array}$ & 0,45 & 0,012 & 33 & 3,333 & 2,000 & $\mathrm{H}_{\mathrm{o}}$ ditolak \\
\hline
\end{tabular}

Hasil analisis uji-t diperoleh $t_{\text {hitung }}=3,333$. Harga tersebut kemudian dibandingkan dengan harga $t_{\text {tabel }}$ dengan $\mathrm{dk}=34+33-2=65$ dan taraf signifikansi $5 \%$ sehingga diperoleh $t_{\text {tabel }}=2,000$ karena $t_{\text {hitung }}=3,333>t_{\text {tabel }}=2,000$ maka Ho ditolak. Hal ini berarti terdapat perbedaan yang signifikan kompetensi pengetahuan IPS antara kelompok yang dibelajarkan melalui model pembelajaran Mind Mapping berbantuan media audio-visual dengan kelompok yang dibelajarkan melalui pembelajaran konvensional pada siswa kelas IV SD Gugus VIII Kecamatan Abiansemal tahun ajaran 2018/2019.

Rata-rata gain skor kompetensi pengetahuan IPS kelompok yang dibelajarkan melalui model pembelajaran Mind Mapping berbantuan media audio-viual yaitu 0,53. Rata-rata gain skor kompetensi pengetahuan IPA kelompok yang dibelajarkan melalui pembelajaran konvensional yaitu 0,45.Namun dilihat dari rata-rata gain skor yang diperoleh bahwa kelompok eksperimen memiliki rata-rata lebih tinggi daripada kelompok kontrol. Hal ini berarti kelompok yang dibelajarkan melalui model pembelajaran Mind Mapping berbantuan media audio-visual berpengaruh terhadap kompetensi pengetahuan IPS pada siswa kelas IV SD Gugus VIII Kecamatan Abiansemal tahun ajaran 2018/2019.

Dengan demikian, model pembelajaran mind mapping berbantuan media audiovisual dapat direkomendasikan dalam pembelajaran siswa khususnya pada kegiatan pembelajaran yang berisi muatan materi IPS. Kegiatan pembelajaran menggunakan model pembelajaran mind mapping berbantuan media audio-visual dilakukan di kelas IV SD No 1 Sibangkaja pada kelompok eksperimen menunjukan bahwa siswa memperdalam pemahamannya mengenai materi pembelajaran, melatih tanggung jawab siswa dalam mengerjakan tugas yang diberikan, siswa dalam mengikuti proses belajar merasa sangat senang, dapat mengembangkan rasa ingin tahu, meningkatkan rasa percaya diri siswa dalam mengemukakan pendapatnya, dan mengembangkan rasa saling memiliki kerjasama antar siswa. Dengan menggunakan model pembelajaran mind mapping memberikan kebebasan berinteraksi dan mengemukakan pendapat siswa didalam kelas, serta memberi pemahaman yang lebih mendalam terhadap pokok bahasan. Selain itu proses pembelajaran menjadi tidak 
membosankan karena dipadukan dengan media audio-visual sehingga dapat membantu memusatkan perhatian siswa terhadap materi yang akan dijelaskan guru melalui media berupa video. Hal tersebut dapat meningkatkan motivasi dan rasa percaya diri siswa dalam mengikuti pembelajaran khususnya muatan materi IPS. Berbeda pada kelompok kontrol, dengan pembelajaran konvensional sebagaimana biasa diterapkan pada kelompok kontrol. Hal tersebut disebubkan kurangnya partisipasi siswa masih belum optimal dikarenakan pembelajaran satu arah serta kurangnya variasi atau penggunaan model pembelajaran khususnya IPS mempengaruhi kompetensi pengetahuan IPS. Pembelajaran menggunakan model mind mapping berbantuan media audio-visual pada penelitian ini memiliki keunggulan ,yaitu tidak hanya membuat siswa lebih aktif tetapi juga membuat siswa berani mengemukakan pendapatnya, menambah kekompakannya dalam berkelompok ,rasa percaya diri siswa serta menambah minta dan pretasi belajar siswa. Kegiatan belajar siswa didalam kelas juga menjadi lebih menarik dengan adanya kegiatan siswa membuat suatu karya yang berupa peta pikiran yang mereka kembangkan bersama kelompok belajarnya didalam kelas serta mampu mengembangkan ideide yang lebih kreatif mengenai muatan materi IPS yang mereka pelajari. Dengan demikian, model pembelajaran mind mapping berbantuan media audio-visual ini mampu meningkatkan hasil belajar siswa khususnya pada muatan materi IPSsemakin meningkat.

Hasil penelitian ini mendukung penelitian Cahyani (2018) yang menyatakan pembelajaran mind mapping adalah suatu pembelajaran yang efektif karena guru dapat merubah pola diskusi kelompok besar menjadi kelompok kecil, sehingga memungkinkan siswa untuk dapat bertukar pikiran dan saling berbagi pendapat dengan leluasa serta dapat meningkatkan rasa tanggung jawab setiap siswa. Model pembelajaran mind mapping berbantuan media audio-visual juga memberikan dampak positif yaitu membantu siswa menghasilkan pembelajaran bermakna dalam kelas. Dengan demikian meskipun saat pmbelajaran menepati jam terakhir pun, siswa tetap antusias belajar.

\section{Simpulan}

Mapping berbantuan media Audio-visual pada siswa kelas IV SD Gugus VIII Kecamatan Abiansemal Tahun Ajaran 2018/2019 diperoleh rata-rata gain skor yaitu 0,53, maka rata-rata kelompok eksperimen dapat dikategorikan cukup baik.

Kompetensi pengetahuan IPS kelompok yang dibelajarkan melalui pembelajaran konvensional pada siswa kelas IV SD Gugus VIII Kecamatan Abiansemal Tahun Ajaran 2018/2019 diperoleh rata-rata gain skor 0,45, maka rata-rata kelompok kontrol dapat dikategorikan cukup baik. Berdasarkan hasil analisis menggunakan uji-t diperoleh $t_{\text {hitung }}=3,333$. Kemudian dibandingkan dengan $t_{\text {tabel }}$ dengan $\mathrm{dk}=65$ pada taraf signifikansi $5 \%$ diperoleh $t_{\text {tabel }}=$ 2,000 . Karena $t_{\text {hitung }}=3,333>t_{\text {tabel }}(\alpha=0,05)=2,000$, ini berarti bahwa terdapat perbedaan yang signifikan kompetensi pengetahuan IPS kelompok yang dibelajarkan melalui model pembelajaran Mind Mapping berbantuan media audio-visual dengan kelompok yang dibelajarkan melalui pembelajaran konvensional pada siswa kelas IV SD Gugus VIII Kecamatan Abiansemal Tahun Ajaran 2018/2019. Rata-rata gain skor kompetensi pengetahuan IPS yang diperoleh kelompok yang dibelajarkan melalui model pembelajaran Mind Mapping berbantuan media audio-visual lebih dari kelompok yang dibelajarkan melalui pembelajaran konvensional $(0,53>0,45)$. Dengan demikian dapat disimpulkan bahwa terdapat pengaruh yang signifikan model pembelajaran Mind Mapping berbantuan media audio-visual terhadap kompetensi pengetahuan IPS pada siswa kelas IV SD Gugus VIII Kecamatan Abiansemal Tahun Ajaran $2018 / 2019$.

Adapun saran yang dapat disampaikan setelah dilaksanakan dan diperoleh hasil dari penelitian sebagai berikut. Berdasarkan temuan pada penelitian ini, disarankan bagi siswa agar memanfaatkan kesempatan yang difasilitasi guru dengan berpartisipasi aktif dalam kegiatan pembelajaran menggunakan model pembelajaran mind mapping berbantuan media audio-visual 
sehingga dapat membangun pengetahuannya sendiri dan pembelajaran siswa menjadi lebih bermakna.

Bagi guru disarankan agar dapat dijadikan acuan dalam pemilihan model pembelajaran yang sesuai dengan kurikulum 2013 dengan melihat karakteristik muatan pembelajaran yang terintegrasi , pendekatan saintifik serta kebutuhan siswa. Kegiatan pembelajaran menjadi lebih inovatif dan variatif karena dapat menggunakan model pembelajaran yang sesuai kurikulum 2013. Salah satu model pembelajaran yang dapat disarankan, yaitu model pembelajaran mind mapping berbantuan media audio-visual, terutama untuk kegiatan pembelajaran yang berisi muatan materi IPS.

Bagi Kepala Sekolah menciptakan kondisi yang mampu mendorong para guru untuk mencoba menerapkan model pembelajaran yang sesuai dengan karakteristik kurikulum 2013 untuk meningkatkan kualitas proses pembelajaran di sekolah.

Bagi peneliti lain hendaknya hasil penelitian ini digunakan sebagai referensi untuk melaksanakan penelitian selanjutnya atau menemukan inovasi kegiatan pembelajaran lainnya yang bermakna dan menyenangkan bagi siswa.

* Corresponding author.

E-mail Addresses: luh.putu.ekayanti@undiksha.ac.id1, iwayan.darsana@undiksha.ac.id2, sujanawyn59@undiksha.ac.id3 


\section{Daftar Pustaka}

Agung, A. A. G. 2014. Metodelogi Penelitian Pendidikan. Yogyakarta: Aditya Media Publishing.

Agung, A. A. G. 2016. Statistika Untuk Dasar Pendidikan. Yogyakarta: Aditya Media Deepublish.

Arsyad, Azhar. 2011.Media Pembelajaran. Jakarta : PT Raja Grafindo Persada.

Dantes. N. 2012. Metode Penelitian. Yogyakarta :CV Andi Offset.

Kementrian Pendidikan dan Kebudayaan. 2014. Peraturan Menteri Pendidikan dan Kebudayaan Republik Indonesia Nomor 57 Tahun 2014. Jakarta: Kemendikbud.

Sardjiyo.2014. Pendidikan IPS di SD. Tanggerang Selatan: Universitas Terbuka.

Setyosari, Punaji. 2015. Metode Penelitian Pendidikan dan Pengembangan. Jakarta: Prenadamedia Group.

Shoimin.2014.68 Model Pembelajaran Inovatif dalam Kurikulum 2013.Yogyakarta:Ar-Ruzz Media

Sugiyono.2016. Metode Penelitian Pendidikan (Pendekatan Kuantitatif, Kualitatif, dam R\&D). Bandung: Alfabeta.

Tri Dhiana Cahyani, Ni Nyoman. 2018. Pengaruh Model Pembelajaran Mind Mapping Berbantuan Media Animasi Terhadap Kompetensi Pengetahuan IPS SD Kelas V Gugus III Kecamatan Kuta Selatan. Jurusan Pendidikan Guru Sekolah Dasar: FIP Undiksha.

Yusuf, A. M. 2015. Asesmen Dan Evaluasi Pendidikan. Jakarta: Kencana. 